\title{
PENGARUH CUSTOMER EXPERIENCE DAN TRUST TERHADAP MINAT BELI ULANG 181 LAYANAN PESAN ANTAR GOFOOD SAAT PANDEMI COVID-19 PADA GENERASI Z
}

\author{
Reza Sri Ayaumi'; Neng Siti Komariah² \\ Fakultas Ekonomi dan Bisnis Universitas Bhayangkara Jakarta Raya ${ }^{\mathbf{1 , 2},}$ \\ rezasriayaumi@gmail.com ${ }^{\mathbf{1}}$, neng.siti@dsn.ubharajaya.ac.id ${ }^{2}$
}

\begin{abstract}
ABSTRAK
Pelayanan pelanggan yang baik menimbulkan Customer Experience dan Trust yang baik juga di mata pelanggan terlebih pada saat pandemi Covid-19 Pelanggan cenderung melakukan pembelian secara online. pengalaman dan kepercayaanya saat bertrantraksi dapat menimbulkan minat untuk melakukan pembelian kembali pada produk tersebut.Penelitian ini dilakukan untuk menguji pengaruh Customer Experience dan Trust terhadap minat beli ulang layanan pesan antar GoFood saat pandemi COVID-19 di Bekasi. Penelitian ini merupakan penelitian kuantitatif dengan objek dalam penelitian ini adalah Generasi Z, pengumpulan data menggunakan kuesioner, serta studi pustaka. Teknik pengambilan sampel menggunakan metode Purposive Sampling. Jumlah sampel yang digunakan dalam penelitian ini adalah 150 responden. Hasil dari uji t penelitian ini menjelaskan bahwa variabel Customer Experiece dan Trust berpengaruh secara parsial terhadap minat beli ulang layanan pesan antar GoFood, dan hasil dari uji F penelitian ini menjelaskan bahwa variabel Customer Experience dan Trust secara simultan berpengaruh terhadap minat beli ulang.
\end{abstract}

Kata kunci : Customer Experience, Trust, Minat Beli Ulang.

Abstract

Good customer service leads to good Customer Experience and Trust in the eyes of customers, especially during the Covid-19 pandemic. Customers tend to make purchases online. experience and trust when trading can generate interest to repurchase the product. This study was conducted to examine the effect of Customer Experience and Trust on the repurchase intention GoFood delivery services during the COVID-19 pandemic in Bekasi. This research is a quantitative research with the object in this research is Generation $Z$, data collection using questionnaires, and literature study. The sampling technique used was the purposive sampling method. The number of samples used in this study were 150 respondents. The results of the t-test of this study explain that the Customer Experience and Trust variables have a partial effect on the repurchase intention GoFood delivery service, and the results of the F-test of this study explain that the Customer Experience and Trust variables simultaneously affect the repurchase intention.

Keywords: Customer Experience, Trust, Repurchase Intention.

Diterima: 8 September 2021; Direvisi:28 September 2021; Diterbitkan: Oktober 2021 


\section{PENDAHULUAN}

Saat ini teknologi mengalami kemajuan pesat yang dapat memudahkan para pelaku bisnis menjalankan bisnisnya, para pelaku bisnis gencar melakukan inovasi guna menarik pelanggan secara luas. Saat ini Sektor belanja online meningkat, terlebih disaat keadaan pandemic Covid-19, yang memaksa pelanggan untuk mengurangi interaksi secara langsung dan beralih ke interaksi secara online. sektor belanja Online yang kini kian diminati adalah melakukan pemesanan pada aplikasi layanan pesan antar dalam hal ini pada layanan pesan antar GoFood. Layanan GoFood disukai lantaran memberikan ke prakatisan. Terlebih pada saat ini layanan pesan antar sangat di sukai oleh generasi $\mathrm{Z}$.

Generasi Z merupakan generasi yang lahir setelah tahun 1995 sampai dengan 2010 yang akrab dengan internet dan lebih banyak berhubungan sosial di dunia maya. Karena lebih banyak berinteraksi secara tidak langsung, generasi $\mathrm{Z}$ dinilai lebih besar minatnya pada pembelian layanan pesan antar makanan terlebih disaat keadaan pandemic Covid-19 ini yang menghasruskan masyarakat untuk menjaga jarak dan mengerjakan segala kegiatan dari rumah. dari pelayanan yang GoFood berikan dapat membentuk Customer Experience dan Trust tersendiri di benak pelangganya. Customer Experience didapat dari respon setelah pembelian, penggunaan, dan kontak tidak langsung seperti kritik dari mulut ke mulut, sedangkan Trust merupakan kesimpulan yang dibuat oleh pelanggan yang menunjukkan persepsi pelanggan.

Semakin kesini penawaran yang di tawarkan layanan pesan antar semakin beragam dan semakin bersaing ketat antara satu sama lain dan antar layanan saling mempertahankan konsumenya untuk dapat menggunakan layanan kembali. Untuk mendapatkan pelanggan kembali, layanan yang diberikan harus mengahasilkan Customer Experience dan Trust yang baik dari pelanggan. pada layanan GoFood didapat beberapa keluhan pelanggan yang terdapat di kolom komentar sosial media resminya atas beberapa ketidaksesuaian dengan harapan pelanggan. dari pengalaman tersebut dapat saja mempengaruhi kepercayaan pelanggan kedepanya.

Saat ini layanan pesan antar GoFood memiliki pesaing yang cukup kuat, satu diantaranya merupakan kompetitor sejak lama, yaitu GrabFood. dan baru baru ini kemunculan ShopeeFood dianggap menjadi pesaing baru diantara dua raksasa layanan pesan antar tersebut, sehingga masingmasing layanan tersebut saling berkompetisi dan berinovasi untuk lebih unggul terlebih dimata pelanggan. pelayanan yang diberikan GoFood dikategorikan baik, dan juga berdasarkan hasil beberapa survei GoFood berhasil mengungguli kompetitornya. Dari keunggulan layanan GoFood dibandingkan kompetitor dapat membuat pelanggan minat untuk melakukan pembelian ulang layanan GoFood.

berdasarkan uaraian di atas, tujuan dari penelitian ini adalah untuk menguji pengaruh dari Customer Experience dan Trust terhadap minat beli ulang generasi $\mathrm{Z}$ pada layanan pesan antar GoFood saat pandemi Covid-19.

\section{LANDASAN TEORI}

\section{Minat Beli Ulang}

Minat beli ulang adalah ketertarikan pelanggan untuk melakukan pembelian Kembali di masa depan, pada produk yang pernah dibelinya berdasarkan pengalaman yang telah diterima sebelumnya. Menurut Phuong et al (2018:81) dalam jurnal (Saidani et al., 2019:427) Minat beli ulang merupakan suatu tingkat motivasional seorang konsumen untuk mengulangi perilaku pembelian pada suatu produk yang sama. 
Minat beli ulang menurut (Anggreni, 2015) adalah proses berulang yang pelanggan lakukan dalam membeli barang atau jasa dari toko tertentu yang dimana alasan utamanya dalam melakukan pembelian ulang adalah pengalaman pelanggan setelah berbelanja. Menurut Kotler (2009:190) dalam jurnal (Yolandari \& Kusumadewi, 2018:5345) minat beli ulang adalah Tindakan setelah proses pembelian. Apabila produk dirasa sudah sesuai dengan harapan pelanggan, maka pelanggan akan melakukan pembelian Kembali, namun apabila ternyata produk mengecewakan maka konsumen akan mencari alternatif lain. Volume penjualan dipengaruhi loyalitas konsumen atau minta beli ulang. Semakin bertambah loyalitas konsumen, maka semakin meningkat volume penjualan (Soehardi, 2021).

\section{Customer Experience}

Customer Experience adalah bentuk interpretasi pengalaman keseluruhan dari pelanggan atas terjadinya interaksi dengan suatu merek baik secara langsung maupun tidak langsung yang bersifat internal dan subjektif. Menurut (Steven Walden, 2017) Customer Experience is those subjectives experiences that lie in memory or are experienced in the moment, that influence and are influenced by our drives which in turn lead to behavior. Berdasarkan definisi tersebut pengalaman pelanggan (Customer Experience) adalah pengalaman subjektif yang terdapat dalam ingatan atau yang dialami pada saat itu, yang mempengaruhi dan dipengaruhi oleh dorongan kita yang pada giliranya mengarah pada perilaku. Sedangkan Frow dan Payne (2007) berpendapat bahwa Customer Experience adalah bentuk interpretasi pengguna terhadap interaksi total pengguna tersebut dengan sebuah merek. Menurutnya mencapai pengalaman pelanggan yang sempurna adalah tujuan setiap organisasi untuk meningkatkan loyalitas dan profitabilitasnya. Menurut Irawan (2006) dalam jurnal (Salim \& Catherine, 2015:325) mengemukakan bahwa pengalaman pelangggan adalah suatu proses, strategi, dan implementasi dari suatu perusahaan untukmengelola pengalaman konsumenya terhadap sebuah produk atau layanan.

\section{Trust}

Kepercayaan adalah keseluruhan pengetahuan dan kesimpulan yang dimiliki pelanggan tentang suatu objek, yang dapat mempengaruhi persepsi pelanggan dengan baik atau positif terhadap objek tersebut. Menurut Sunarto (2009:153) dalam jurnal (Rosdiana et al., 2019:321) Kepercayaan adalah semua pengetahuan yang dimiliki oleh konsumen dan semua kesimpulan yang dibuat oleh konsumen tentang suatu objek, atribut, maupun manfaatnya yang dapat menunjukkan persepsi konsumen. Sedangkan pengertian kepercayaan menurut Sangadji dan Sopiah (2013:201) dalam jurnal (Ardianto, Nuriska, \& Nirawati, 2020:66) merupakan keseluruhan pengetahuan yang dimiliki oleh pelanggan, dan semua kesimpulan yang dibuat oleh pelanggan tentang objek, atribut, dan manfaatnya. Pendapat lain dikamukakan oleh Supriyono (2010) menurutnya Trust adalah kepercayaan pihak tertentu terhadap yang lain dalam melakukan suatu transaksi berdasarkan atas keyakinan bahwa pihak yang dipercayainya tersebut akan memenuhi segala kewajibanya dengan baik sesuai yang diharapkan.

\section{Kerangka Penelitian}

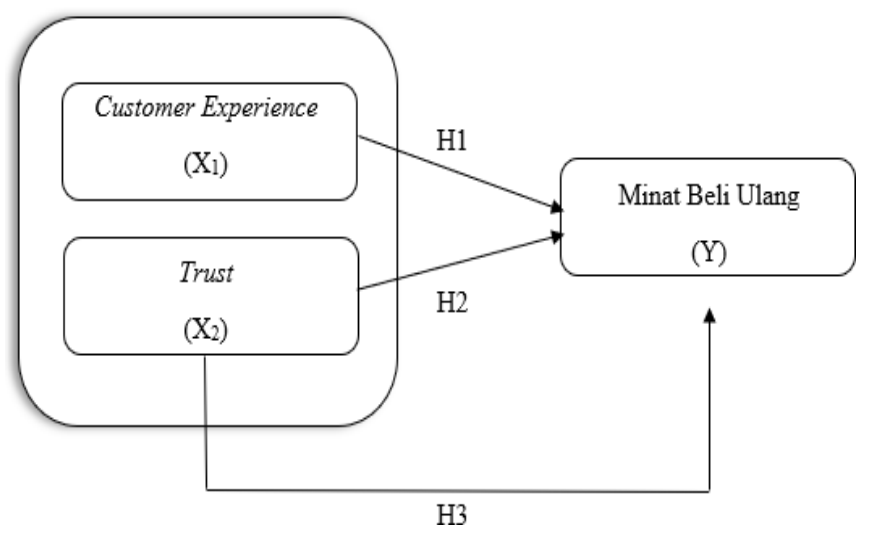




\section{Hipotesis}

Hipotesis yang dirumuskan adalah:

H1 : Diduga Customer Experience berpengaruh signifikan terhadap Minat Beli Ulang.

H2 : Diduga Trust berpengaruh signifikan terhadap Minat Beli Ulang.

H3 : Diduga Customer Experience dan Trust berpengaruh signifikan terhadapMinat Beli Ulang.

\section{METODE PENELITIAN}

Metode analisis data yang digunakan dalam penelitian ini adalah metode Analisis Kuantitatif menggunakan software SPSS. Objek dalam penelitian ini adalah Generasi Z yang menggunakan layana pesan antar GoFood.

\section{Populasi \& Sampel}

Populasi dalam penelitian ini adalah seluruh Generasi $\mathrm{Z}$ yang menggunakan layanan pesan antar GoFood. Sampel yang diambil dari populasi tersebut menggunakan Teknik pengambilan sampel Nonprobability Sampling yaitu Purposive Sampling dengan

\section{Variabel Yang Diteliti}

Guna mempermudah pembahasan dalam penulisan jurnal, penelitian ini mendefinisikan variabel- variabel.

Menurut Sujarweni (2015) variabel bebas adalah variabel yang dapat mempengaruhi atau yang dapat menjadi sebab perubahanya atau timbulnya variabel dependen dalam penelitian ini Minat Beli Ulang. Variabel independen dalam penelitian ini adalah Customer Experience (X1) dan Trust (X2) beberapa kriteria yang sudah ditentukan, dengan Teknik pengumpulan sampel menggunakan runus Hair, et, al (1995) yang menyatakan ukuran sampel minimum sebanyak 5 observasi untuk setiap estimated parameter dan maksimal adalah 10 observasi dari setiap estimated parameter. Sampel = Jumlah Indikator x 10. Yaitu, Sampel = $15 \mathrm{x}$ $10=150$ (Sampel/ Responden). Teknik pengumpulan data dalam penelitian ini adalah pengumpulan data dalam penelitian ini adalah menggunakan kuesioner melalui Google Form. Operasional Variabel Penelitian ini adalah sebagai berikut:

Tabel 1. Operasional Variabel Penelitian

\begin{tabular}{cccc}
\hline No. & variabel & \multicolumn{1}{c}{ Indikator } & Butir Instrumen \\
\hline 1. & Customer Experience & 1.Perceived ease of use & $\mathrm{X} 1.1$ \\
& $\left(\mathrm{X}_{1}\right)$ & 2. Customer Review & $\mathrm{X} 1.2$ \\
& & 3. Customization & $\mathrm{X} 1.3$ \\
& & 4. Security & $\mathrm{X} 1.4$ \\
& & 5.Fulfillment Reliability & $\mathrm{X} 1.5$ \\
& & 6. Customer Service & $\mathrm{X} 1.6$ \\
& & 7. Store Offering & $\mathrm{X} 1.7$ \\
\hline 2. & Trust $\left(\mathrm{X}_{2}\right)$ & 1.Kehandalan & $\mathrm{X} 2.1$ \\
& & 2.Kejujuran & $\mathrm{X} 2.2$ \\
& & 3.Kepedulian & $\mathrm{X} 2.3$ \\
& & 4.Kredibilitas & $\mathrm{X} 2.4$ \\
\hline 3. & Minat Beli Ulang $(\mathrm{Y})$ & 1.Minat Transaksional & $\mathrm{Y} .1$ \\
& & 2.Minat Referensial & $\mathrm{Y} .2$ \\
& & 3.Minat Preferensial & $\mathrm{Y} .3$ \\
& & 4.Minat Eksploratif & $\mathrm{Y} .4$ \\
\hline
\end{tabular}

Adapun operasional variabel yang dapat dirumuskan sebagai berikut:

1. Indikator Variabel Customer Experience menurut Nilsson dan Wall (2017:4) dalam jurnal (Cahyani, Gunadi, \& Mbulu, 2019:29) yaitu sebagai berikut

1.Perceived ease of use

2. Customer Review

3. Customization

4. Security

5.Fulfillment Reliability

6. Customer Service

7. Store Offering 
regresi digunakan untuk menguji kebenaran hipotesis yang diajukan dalam penelitian ini

\section{Uji Hipotesis}

\section{Uji Parsial (Uji t)}

Menurut Sujarweni (2015) uji parsial digunakan untuk dapat mengetahui apakah variabel independen (X) secara individual mempengaruhi variabel dependen (Y). dangan taraf signifikan 5\%. Dengan ketentuan Jika Sig. < 0,05, Maka Ho ditolak Ha diterima dan sebaliknya.

\section{Uji Simultan (Uji F)}

Menurut Sujarweni (2015) uji $F$ merupakan pengujian signifikansi persamaan yang digunakan untuk dapat mengetahui seberapa besar pengaruh variabel independen $\left(\mathrm{X}_{1} \mathrm{X}_{2}\right)$ secara bersamasama terhadap variabel dependen (Y). Dengan ketentuan jika Jika Sig. < 0,05, Maka Ho ditolak Ha diterima dan sebaliknya

\section{Analisis Koefisien Determinasi ( $\left.\mathbf{R}^{2}\right)$}

Menurut Sujarweni (2015) koefisien determinasi digunakan untuk mengetahui presentase perubahan variabel dependen $(\mathrm{Y})$ yang disebabkan oleh variabel independen (X). jika $\mathrm{R}^{2}$ semakin besar, maka presentase perubahan variabel dependen ( $\mathrm{Y}$ ) yang disebabkan oleh variabel independen (X) semakin tinggi. Dan jika $\mathrm{R}^{2}$ semakin kecil, maka presentase perubahan variabel dependen $(\mathrm{Y})$ yang disebabkan oleh variabel independen (X) semakin rendah.

\section{HASIL PENELITIAN PEMBAHASAN}

\section{Uji Validitas}

Pada uji instrumen dilakukan penyebaran kuesioner pada Generasi $\mathrm{Z}$ yang berdomisili di Bekasi, dengan memberikan responden 15 butir pertanyaan. Untuk Rtabel dengan jumlah data $(\mathrm{N})=30$, dimana $\mathrm{df}=\mathrm{n}-2$ adalah $30-2=28$. Sehingga hasil yang diperoleh untuk R-tabel adalah 0,3610. Lebih lengkapnya dapat dilihat dalam tabel berikut.

Tabel 2. Uji Validitas CustomerExperience (X1)

\begin{tabular}{cccc}
\hline Item & R Hitung & R Tabel & Keterangan \\
\hline $\mathrm{X} 1.1$ & 0,676 & 0,3610 & Valid \\
\hline $\mathrm{X} 1.2$ & 0,599 & 0,3610 & Valid \\
\hline $\mathrm{X} 1.3$ & 0,699 & 0,3610 & Valid \\
\hline $\mathrm{X} 1.4$ & 0,597 & 0,3610 & Valid \\
\hline $\mathrm{X} 1.5$ & 0,843 & 0,3610 & Valid \\
\hline $\mathrm{X} 1.6$ & 0,719 & 0,3610 & Valid \\
\hline $\mathrm{X} 1.7$ & 0,761 & 0,3610 & Valid
\end{tabular}

Sumber : Data Peneliti (2021)

Tabel 3. Uji Validitas Trust (X2)

\begin{tabular}{cccc}
\hline Item & R Hitung & R Tabel & Keterangan \\
\hline $\mathrm{X} 2.1$ & 0,716 & 0,3610 & Valid \\
\hline $\mathrm{X} 2.2$ & 0,822 & 0,3610 & Valid \\
\hline $\mathrm{X} 2.3$ & 0,730 & 0,3610 & Valid \\
\hline $\mathrm{X} 2.4$ & 0,864 & 0,3610 & Valid \\
\hline
\end{tabular}

Sumber : Data Peneliti (2021)

Tabel 4. Uji Validitas Minat Beli Ulang(Y)

\begin{tabular}{cccc}
\hline Item & R Hitung & R Tabel & Keterangan \\
\hline X2.1 & 0,802 & 0,3610 & Valid \\
\hline X2.2 & 0,695 & 0,3610 & Valid \\
\hline X2.3 & 0,803 & 0,3610 & Valid \\
\hline X2.4 & 0,846 & 0,3610 & Valid
\end{tabular}

Sumber : Data Peneliti (2021)

Dari hasil uji validitas dapat diketahui bahwa nilai R-hitung yang didapatkan oleh masing-masing pertanyaan memiliki nilai $\mathrm{R}$ hitung yang

lebih besar dari pada R-tabel yang mana memiliki nilai 0,3610 . Sehingga dapat disimpulkan bahwa masing-masing butir 
pertanyaan yang ada pada variabel Minat Beli Ulang dinyatakan valid.

\section{Uji Reliabilitas}

Tabel 5. Uji Reliabilitas

\begin{tabular}{llccc}
\hline N0 & Variabel & Alpha Cronbach & Kriteria & Keterangan \\
\hline 1. & Customer Experience & 0,824 & 0,60 & Reliabel \\
\hline 2. & Trust & 0,789 & 0,60 & Reliabel \\
\hline 3. & Minat Beli Ulang & 0,793 & 0,60 & Reliabel \\
\hline \hline
\end{tabular}

Sumber : Data Peneliti (2021)

Pada tabel 5. Menunjukkan bahwa nilai dari Alpha Cronbach dari variabel Customer Experience sebesar 0,824, Trust sebesar 0,789, dan Minat Beli Ulang sebesar 0,793. Dengan demikian dapat diambil kesimpulan bahwa peryataan dalam kuesioner ini reliabel karena memiliki nilai Alpha Cronbach lebih besar dari o,600.

\section{Uji Asumsi Klasik}

\section{Uji Normalitas}

Tabel 6. Uji Normalitas

One-Sample Kolmogorov-Smirnov Test

\begin{tabular}{llr}
\hline & & \multicolumn{2}{c}{ Unstandardized } \\
Residual
\end{tabular}

Pada tabel 6. Dapat dilihat bahwa nilai Asymp Sig. (2-tailed) sebesar 0,200 > 0,050 hal ini dapat membuktikan bahwa data berdistribusi normal.

\section{Uji Multikolinearitas}

Tabel 7. Uji Multikolinearitas

$$
\text { Coefficients }^{a}
$$

\begin{tabular}{|c|c|c|c|}
\hline \multirow{2}{*}{\multicolumn{2}{|c|}{ Model }} & \multicolumn{2}{|c|}{$\begin{array}{l}\text { Collinearity } \\
\text { Statistics }\end{array}$} \\
\hline & & Tolerance & VIF \\
\hline \multirow[t]{2}{*}{1} & $\begin{array}{l}\text { Customer } \\
\text { Experience }\end{array}$ & .423 & 2.363 \\
\hline & Trust & .423 & 2.363 \\
\hline
\end{tabular}

a. Dependent Variable: Minat Beli Ulang

Berdasarkan hasil Output tersebut, dapat diketahui bahwa nilai VIF untuk Customer Experience dan Trust adalah 2,363. dan didapat nilai tolerance untuk Customer Experience dan Trust adalah 0,423 . Karena nilai VIF lebih kecil dari 10 dan nilai tolerance lebih besar dari o,10 maka dapat disimpulkan tidak terjadi Multikolinearitas atau analisis ini bebas dari asumsi Multikolinearitas.

\section{Uji Heteroskedastisitas}

Berikut hasil Uji Heteroskedastisitas menggunakan IBM SPSS versi 23 :

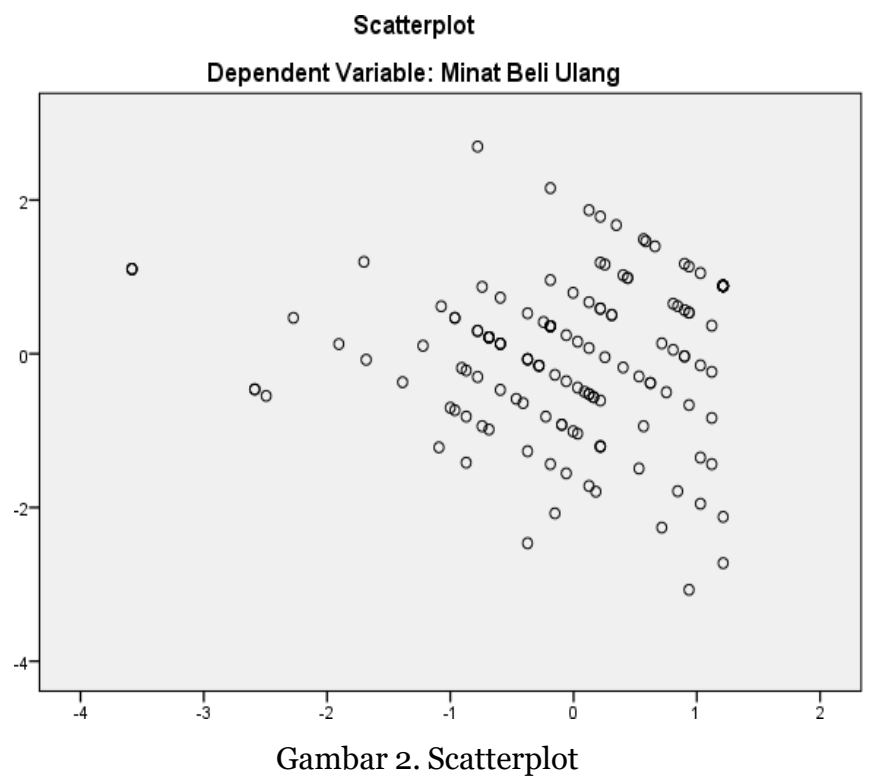


Pada gambar 2. Menunjukkan bahwa titik-titik menyebar secara acak dengan titiktitik menyebar di atas dan di bawah atau sekitar angka o, titik- titik tidak mengumpul di atas atau dibawah saja, penyebaran titiktitik tidak bergelombang, melebar kemudian menyempit kembali dan melebar kembali, dan penyebaran titik tidak berpola. Sehingga tidak terjadi heteroskedastisitas pada model regresi.

Tabel 8. Hasil Uji Glejser

Coefficients ${ }^{\mathrm{a}}$

\begin{tabular}{|c|c|c|c|c|c|c|}
\hline \multirow{2}{*}{\multicolumn{2}{|c|}{ Model }} & \multicolumn{2}{|c|}{$\begin{array}{r}\text { Unstandardized } \\
\text { Coefficients }\end{array}$} & \multirow{2}{*}{$\begin{array}{c}\begin{array}{c}\text { Standardized } \\
\text { Coefficients }\end{array} \\
\text { Beta }\end{array}$} & \multirow{2}{*}{$\mathrm{t}$} & \multirow{2}{*}{ Sig. } \\
\hline & & B & Std. Error & & & \\
\hline \multirow[t]{3}{*}{1} & (Constant) & -.361 & .681 & & -.531 & .596 \\
\hline & $\begin{array}{l}\text { Customer } \\
\text { Experience }\end{array}$ & -.011 & .030 & -.044 & -.356 & .723 \\
\hline & Trust & .113 & .058 & .242 & 1.948 & .053 \\
\hline
\end{tabular}

a. Dependent Variable: Abs_RES

Apabila nilai Signifikansi (sig) lebih besar dari 0,05 maka tidak terjadi gejala heteroskedastisitas. Berdasarkan hasil uji Glejser pada output di atas, terdapat bahwa nilai Sig. dari masing -masing variabel Customer Experience sebesar 0,723 dan Trust sebesar 0,053 menunjukkan angka yang lebih besar dari 0,05 artinya tidak terdapat masalah heteroskedastisitas pada penelitian ini.

\section{Analisis Regresi Linier Berganda}

Tabel 9. Analisis Regresi Linier Berganda

Coefficients $^{\mathrm{a}}$

\begin{tabular}{|c|c|c|c|c|c|}
\hline \multirow{2}{*}{ Model } & \multicolumn{2}{|c|}{$\begin{array}{l}\text { Unstandardized } \\
\text { Coefficients }\end{array}$} & $\begin{array}{l}\text { Standardized } \\
\text { Coefficients }\end{array}$ & \multirow{2}{*}{$t$} & \multirow{2}{*}{ Sig. } \\
\hline & B & Std. Error & Beta & & \\
\hline (Constant) & 4.090 & 1.153 & & 3.546 & .001 \\
\hline CustomerExperience & .140 & .050 & .261 & 2.787 & .006 \\
\hline Trust & .477 & .098 & .454 & 4.844 & .000 \\
\hline
\end{tabular}

a. Dependent Variable: Minat Beli Ulang
Berdasarkan tabel 9. diperoleh persamaan resgresi linier berganda sebagai berikut:

$$
\mathrm{Y}=4,090+0,140 \mathrm{X}_{1}+0,477 \mathrm{X}_{2}+\mathrm{e}
$$

Model persamaan regresi linier berganda tersebut memiliki arti sebagai berikut :

\section{Konstanta sebesar 4,090}

Jika pada variabel Customer Experience dan Trust di asumsikan tetap maka Minat Beli Ulang akan bertambah sebesar 4,090.

\section{Koefisien Customer Experience $\left(\mathrm{X}_{1}\right)$}

Nilai koefisien dari Customer Experience sebesar 0,140. Menyatakan bila setiap ada kenaikan 1 skor untuk Customer Experience akan diikuti terjadi kenaikan Minat Beli Ulang sebesar 0,140. Artinya semakin tinggi nilai dari $\mathrm{X}_{1}$, maka nilai $\mathrm{Y}$ juga semakin tinggi.

\section{Koefisien Trust $\left(\mathrm{X}_{2}\right)$}

Nilai koefisien dari Trust sebesar 0,477 . Menyatakan bila setiap ada kenaikan 1 skor untuk Trust akan diikuti terjadi kenaikan Minat Beli Ulang sebesar 0,477. Artinya semakin tinggi nilai dari $\mathrm{X}_{1}$, maka nilai $\mathrm{Y}$ juga semakin tinggi.

\section{Uji Hipotesis}

\section{Uji Parsial}

Pengujian dilakukan dengan membandingkan $\mathrm{t}$ hitung dengan $\mathrm{t}$ tabel. pada uji t dengan derajat kebebasan "Degree Of Freedom" (df) = n-k-1 dengan tingkat kepercayaan 95\%, $\alpha=0.05 . \mathrm{t}$ tabel $=\mathrm{t}(\alpha / 2$ $(0,05 / 2)=0,025 ; \mathrm{n}-\mathrm{k}-1)=\mathrm{t}(0,025 ; 150-2-$ 1=147) dari pehitungan tersebut diperoleh nilai t tabel sebesar 1,976 
Tabel 10. Hasil Uji t

Coefficients $^{\mathrm{a}}$

\begin{tabular}{|c|c|c|c|c|c|}
\hline \multirow{2}{*}{ Model } & \multicolumn{2}{|c|}{$\begin{array}{r}\text { Unstandardized } \\
\text { Coefficients }\end{array}$} & \multirow{2}{*}{$\begin{array}{c}\begin{array}{c}\text { Standardized } \\
\text { Coefficients }\end{array} \\
\text { Beta }\end{array}$} & \multirow{2}{*}{ t } & \multirow{2}{*}{ Sig. } \\
\hline & B & Std. Error & & & \\
\hline (Constant) & 4.090 & 1.153 & & 3.546 & .001 \\
\hline CustomerExperience & . 140 & . 050 & .261 & 2.787 & .006 \\
\hline Trust & .477 & .098 & .454 & 4.844 & .000 \\
\hline
\end{tabular}

a. Dependent Variable: Minat Beli Ulang

Berdasarkan table 10. Mengenai hasil uji t dapat diketahui sebagai berikut :

1. Variabel Customer Experience diperoleh

nilai $\mathrm{t}$ hitung sebesar 2,787 dengan tingkat signifikansi sebesar 0,006 jika dibandingkan dengan $t$ tabel $(1,976)$ maka $\mathrm{t}$ hitung $>\mathrm{t}$ tabel dan $\mathrm{p}<0,05$. Dalam hal ini bahwa Ha diterima dan Ho ditolak, sehingga Customer Experience secara parsial berpengaruh terhadap Minat Beli Ulang.

2. Variabel Trust diperoleh nilai t hitung sebesar 4,844 dengan tingkat signifikansi sebesar 0,00o jika dibandingkan dengan t tabel $(1,976)$ maka t hitung $>t$ tabel dan $\mathrm{p}<0,05$. Dalam hal ini bahwa Haditerima dan Ho ditolak, sehingga Customer Experience secara parsial berpengaruh terhadap Minat Beli Ulang.

\section{Uji Simultan}

Pengujian dilakukan dengan membandingkan $\mathrm{F}$ hitung dan $\mathrm{F}$ tabel. Menentukan $\mathrm{F}$ tabel dengan menggunakan $\mathrm{F}$ tabel $=\mathrm{F}(\mathrm{k} ; \mathrm{n}-\mathrm{k})=\mathrm{F}(2 ; 150-2)=158$ Dari perhitungan tersebut diperoleh $\mathrm{F}$ tabel sebesar 3,06.
Tabel 11. Hasil Uji F

\begin{tabular}{|c|c|c|c|c|c|c|}
\hline \multicolumn{7}{|c|}{ ANOVA $^{\mathrm{a}}$} \\
\hline \multicolumn{2}{|c|}{ Model } & $\begin{array}{l}\text { Sum of } \\
\text { Squares }\end{array}$ & $\mathrm{df}$ & $\begin{array}{l}\text { Mean } \\
\text { Square }\end{array}$ & $\mathrm{F}$ & Sig. \\
\hline \multirow[t]{3}{*}{$\overline{1}$} & Regression & 344.301 & 2 & 172.151 & 61.130 & $.000^{b}$ \\
\hline & Residual & 413.972 & 147 & 2.816 & & \\
\hline & Total & 758.273 & 149 & & & \\
\hline
\end{tabular}

Dari tabel 11. diatas diperoleh nilai $\mathrm{F}$ hitung sebesar 61.130 > 3,06 (F tabel) dengan nilai sig.o,ooo maka signifikansi kurang dari 0,05. Dalam hal ini Ha diterima dan Ho

ditolak yang berarti bahwa secara simultan atau bersama-sama Customer Experience $\left(\mathrm{X}_{1}\right)$ dan Trust $\left(\mathrm{X}_{2}\right)$ berpengaruh terhadap Minat Beli Ulang (Y).

\section{Uji Koefisien Determinasi ( $\left.R^{2}\right)$}

Determinasi $\left(\mathrm{R}^{2}\right)$ mencerminkan kemampuan variabel dependen.

Tabel 12. Uji Koefisien Determinasi (R2)

Model Summary ${ }^{b}$

\begin{tabular}{lrrrr}
\hline Model & R & R Square & $\begin{array}{c}\text { Adjusted R } \\
\text { Square }\end{array}$ & $\begin{array}{l}\text { Std. Error of } \\
\text { the Estimate }\end{array}$ \\
\hline 1 & $.674^{\mathrm{a}}$ & .454 & .447 & 1.678 \\
\hline
\end{tabular}

a. Predictors: (Constant), Trust, Customer Experience

b. Dependent Variable: Minat Beli Ulang

Dari hasil analisis koefisien determinasi $\left(\mathrm{R}^{2}\right)$ pada tabel 12. Diketahui nilai $\mathrm{R}$ square sebesar 0,454 atau sama dengan 45,4\% pada variabel Customer Experience dan Trust secara Bersama-sama mempengaruhi Minat Beli Ulang dikategorikan baik. Sedangkan sisanya 
sebesar 54,6\% dipengaruhi oleh variabel lain yang tidak dibahas dalam penelitian ini.

\section{Pembahasan}

Pada hasil uji t Customer Experience $\left(\mathrm{X}_{1}\right)$ terhadap Minat Beli Ulang (Y) memperoleh nilai t hitung sebesar 2,787 >1,976 dengan signifikansi sebesar 0,006 < 0,05 sehingga dapat dikatakan Customer Experience $\left(\mathrm{X}_{1}\right)$ berpengaruh signifikan terhadap Minat Beli Ulang (Y) dan hipotesis pertama diterima.

Pada hasil uji t Trust $\left(\mathrm{X}_{2}\right)$ terhadap Minat Beli Ulang (Y) memperoleh nilai t hitung sebesar 4,844 > 1,976 dengan signifikansi sebesar $0,000<0,05$. sehingga dapat dikatakan Trust $\left(\mathrm{X}_{2}\right)$ berpengaruh signifikan terhadap Minat Beli Ulang (Y) dan hipotesis kedua di terima.

Pada hasil uji $\mathrm{F}$ variabel Customer Experience $\left(\mathrm{X}_{1}\right)$ dan Trust $\left(\mathrm{X}_{2}\right)$ terhadap Minat Beli Ulang memberikan hasil pada $\mathrm{F}$ Hitung lebih besar dari F tabel dimana 61.130 $>$ 3,06 dengan nilai signifikansi 0,000 kurang dari 0,005. sehingga variabel Customer Experience $\left(\mathrm{X}_{1}\right)$ dan Trust $\left(\mathrm{X}_{2}\right)$ secara Bersama-sama berpengaruh signifikan terhadap Minat Beli Ulang (Y) dan hipotesis ketiga diterima.

\section{KESIMPULAN}

Berdasarkan dari hasil penelitian dan pembahasan, maka kesimpulan yang dapat ditarik adalah sebagai berikut :

1. Berdasarkan hasil penelitian bahwa Customer Experience dari pelanggan GoFood yang merupakan Generasi Z berpengaruh dan signifikan terhadap Minat Beli Ulang Layanan Pesan Antar GoFood. Hal ini berarti terdapat pengalaman yang baik yang telah dirasakan oleh Generasi Z saat menggunakan layanan pesan antar GoFood. Hasil menunjukkan tidak seluruhnya pelanggan layanan GoFood kecewa akan pelayanan yang didapatkan, dari hasil indikator Security memiliki nilai yang tinggi, yang membuktikan pelanggan memiliki Experience yang baik pada keamanan (Security) saat transaksi maupun aman pada makanan yang dibawa mitra driver untuk sampai ke tangan konsumen.

2. Berdasarkan hasil penelitian bahwa Trust dari pelanggan GoFood yang merupakan Generasi Z berpengaruh dan signifikan terhadap Minat Beli Ulang Layanan Pesan Antar GoFood. Dalam hal ini berarti tingkat kepercayaan pelanggan terhadap layanan GoFood dapat dikategorikan baik. Hasil menunjukkan nilai yang tinggi pada kehandalan, yang berarti pelanggan memiliki kepercayaan bahwa GoFood dapat diandalkan terutama dalam kondisi saat ini

3. Berdasarkan hasil penelitian Customer Experience dan Trust berpengaruh secara Simultan terhadap Minat Beli Ulang. Dengan diterimanya $\mathrm{H} 3$, yaitu "Customer Experience dan Trust berpengaruh signifikan terhadap Minat Beli Ulang Generasi Z pada Layanan Pesan Antar GoFood Saat Pandemi Covid-19. Hasil menunjukkan minat pelanggan untuk mereferensikan/ merekomendasikan GoFood pada keluarga, teman dan kerabat cenderung tinggi.

\section{Implikasi Manajerial}

Implikasi yang dapat diambil dalam penelitian ini, antara lain :

1. Berdasarkan hasil dari penelitian diketahui Customer Experience berpengaruh terhadap Minat Beli Ulang Generasi Z pada layanan pesan antar GoFood saat pandemic Covid-19. Maka dari itu bagi pihak GoFood dengan performanya yang saat ini diharapkan dapat mempertahankan pelangganya dengan memberikan pengalaman pelanggan terbaik, terlebih pada 
Customer Service GoFood yang dirasa pelayananya kurang baik saat pelanggan memerlukan bantuan. Respon aktif dan cepat tanggap diperlukan agar penanganan pelanggan lebih baik, sehingga selalu timbul pengalaman yang baik dari pelanggan terhadap layanan pesan antar GoFood

2. Berdasarkan hasil dari penelitian dikatahui Trust berpengaruh terhadap Minat Beli Ulang Generasi Z pada layanan pesan antar GoFood saat pandemic Covid-19. Maka dari itu bagi pihak GoFood diharapkan agar dapat tetap menjaga kepercayaan pelangganya dengan baik, terlebih dengan mengedepankan kepedulianya kepada pelanggan, dalam hal ini manajemen GoFood dapat melakukan pendisiplinan pada mitranya baik merchant maupun driver agar tidak ada kesalahan prosedur pelayanan yang diberikan kepada pelanggan sehingga

\section{DAFTAR PUSTAKA}

Anggreni, P. (2015). Pengaruh Perceived Value Terhadap Kepuasan Dan Minat Beli Ulang Pelanggan Pasar Umum Ubud. Telaah Bisnis, 16(2), 110-118.

Ardianto, K., Nuriska, F. P., \& Nirawati, L.

(2020). Pengaruh Kepercayaan Dan Ulasan Produk Terhadap Minat Beli Ulang Emina Pada Official StoreShopee

Di Kota Surabaya. Jurnal Ilmiah Manajemen Ubhara, 2(2), 6272.

Ayuwardani, R. P., \& Isroah, I. (2018). Pengaruh Informasi Keuangan Dan Non Keuangan Terhadap Underpricing Harga Saham Pada Perusahaan Yang Melakukan Initial Public Offering (Studi Empiris Perusahaan Go Public Yang Terdaftar Di Bursa Efek Indonesia Tahun 2011-2015). Nominal, Barometer Riset Akuntansi Dan Manajemen, $\quad 7(1), \quad$ 143-158. pelanggan tidak merasa tidak dipedulikan, dan pelanggan merasa menjadi prioritas.

3. berdasarkan hasil dari penelitian diketahui Customer Experience dan Trust berpengaruh secara Bersama-sama terhadap Minat Bali Ulang Generasi Z pada layanan pesan antar GoFood saat pandemic Covid-19. Maka dari itu bagi Pihak GoFood diharap dapat mempertahankan dan meningkatkan pengalaman serta kepercayaan pelanggan dengan memberi yang terbaik pada pelanggan, dan juga melakukan penyesuaian khususnya terhadap kebutuhan pelanggan generasi $\mathrm{Z}$ sehingga pelanggan dapat terus ingin melakukan lebih banyak transaksi pada layanan pesan antar GoFood. Jika semua variabel ini terus ditingkatkan maka dapat mempengaruhi minat beli ulang pelanggan layanan pesan antar GoFood terlebih disaat keadaan pandemi ini.

\section{Https://Doi.Org/10.21831/Nominal.V7} i1.19781

Cahyani, A., Gunadi, I. M. A., \& Mbulu, Y. P. (2019). Pengaruh Customer Experience Terhadap Repurchase Intention PadaPt. Traveloka Indonesia. Jurnal Sains Terapan Pariwisata, 4(1), 25-36.

Frow, P., \& Payne, A. (2007). Towards The “ Perfect ' Customer. 15(2), 89-101. Https://Doi.Org/10.1057/Palgrave.Bm .2550120

Rosdiana, R., Haris, I. A., \& Suwena, K. R. (2019). Pengaruh Kepercayaan Konsumen Terhadap Minat Beli ProdukPakaian Secara Online. Jurnal Pendidikan Ekonomi Undiksha, 11(1), 318.

Https://Doi.Org/10.23887/Jjpe.V11i1. 20164

Saidani, B., Ekonomi, F., Negeri, U., Lusiana, L. M., Ekonomi, F., Negeri, U., Pembelian, M. (2019). Analisis Pengaruh Kualitas Website Dan Kepercayaan Terhadap Kepuasan Pelanggan Dalam Membentuk Minat Pembelian Ulang Pada Pelanggan Shopee. Jurnal Riset Manajemen Sains 
Indonesia (Rjmsi), 1O(2), 425-444. Https://Doi.Org/Doi.Org/10.21009/Jr msi.010.2.10

Salim, K. F., \& Catherine. (2015). Pengaruh Customer Experience Dan Kepercayaan Terhadap Kepuasan Konsumen Di Tx Travel Klampis. Jurnal Hospitality Dan Manajemen Jasa, 3(1), 322-340.

Soehardi, S. (2021b). Model Peningkatan Volume Penjualan Melalui Kualitas Produk, Kualitas Pelayanan Dan Loyalitas Kopi Golda. Jurnal Manajemen Strategi Dan Aplikasi Bisnis, 4(2), 353-360. https://doi.org/http://ejournal.imperi uminstitute.org/index.php/JMSAB/art icle/view/398

Steven Walden. (2017). Customer Experience Management Rebooted: Are You An Experience Brand Or An Efficiency Brand? Https://Doi.Org/10.1057/978-1-34994905-2

Supriyono, S. (2010). Kepercayaan Dan Minat Beli Di Sub Forum Jual Beli Www.Kaskus.Us. Jurnal Riset Ekonomi Dan Bisnis, 1O(2), 73-82. Https://Doi.Org/10.1234/Jrebis.V10i2 .343

Yolandari, N. L. D., \& Kusumadewi, N. M. W. (2018). Pengaruh Pengalaman Pelanggan Dan Kepercayaan Terhadap Niat Beli Ulang Secara Online Melalui Kepuasan Pelanggan (Studi Pada Situs Online Berrybenka.Com). E-Jurnal
Manajemen Universitas Udayana, 7(10), 5343. Https://Doi.Org/10.24843/Ejmunud.2 018.V07.I10.Po6

Sujarweni, V. W. (2015). Metodologi Penelitian:Bisnis \& Ekonomi. Bantul Yogyakarta: Pustakabarupress.

Tegowati. (2016). Minat Beli Ulang Handphone Evercross Dipusat Perbelanjaan Handphone Wtc Surabaya. Jurnal Penelitian Ilmu Manajemen, 2(2), 406- 416. Https://Doi.Org/Http://Dx.Doi.Org/1 0.30736\%2fjpim.V2i2.51 